\title{
Assessment of knowledge and awareness of "sustainability" initiatives among college students
}

\author{
Israel Msengi ${ }^{1,}$, , Raymond Doe ${ }^{2}$, Twana Wilson ${ }^{3}$, Danny Fowler $^{3}$, Chelsey Wigginton ${ }^{3}$, Sarah Olorunyomi ${ }^{3}$, \\ Isaiah Banks ${ }^{3}$, and Raquel Morel ${ }^{3}$ \\ ${ }^{1}$ Health Kinesiology Department, Lamar University, Beaumont, TX 77705, USA \\ 2 Department of Psychology, Lamar University, Beaumont, TX 77705, USA \\ ${ }^{3}$ Health and Environmental Education Corps, Lamar University, Beaumont, TX 77705, USA
}

Received: 26 July 2018 / Received in final form 28 December 2018 / Accepted: 7 January 2019

\begin{abstract}
Campus sustainability is essential for any university. Campus sustainability denotes the potential of the university to develop new ideas regarding sustainability through research, teaching, and practices. It necessitates improved academic infrastructures, setting right faculty priorities and practices that ensure that the university community is aware of sustainable practices, and that its practices reflect sustainability. This study assesses college students' knowledge and awareness of sustainability issues. After IRB approval, data were collected using the campus sustainability questionnaire. Students from a university in the southeastern part of Texas in the United States were selected and asked to participate in the study voluntarily by answering a selfreport questionnaire. Findings indicate that only a minority of the students knew what sustainability was, but $95.8 \%$ indicated it was important. Although the university has committed to climate and sustainability agreements, majority of the students were not aware of it and only about $17 \%$ knew that the University's Strategic Plan has a sustainability component. Nearly $36 \%$ of the students reported receiving information about sustainability during their campus orientation. In terms of recycling, majority of the students indicated unawareness of e-waste recycling on campus; however, more than $70 \%$ reported that the library limited free printing in computer labs. More than half of the students also indicated that sustainability issues were not infused into curriculum courses or programs, and they had no knowledge of any alternative power source for the university. We concluded that a majority of the students were not conversant with sustainability issues and were largely unaware of campus sustainability initiatives. We recommended more effort to increase sustainability initiatives on campus by involving faculty, staff, and students in such endeavors. Educational programs should incorporate sustainability into their curriculum to increase students' knowledge and consciousness regarding these issues.
\end{abstract}

\section{Introduction}

Healthy ecosystems and environments provide vital goods and services to humans and other living organisms [1-3]. In the twenty-first century, we are witnessing a growing number of people and rising levels of consumption per capita. Human inability to fit their activities into a pattern that conserves the environment and saves energy is fundamentally changing the planetary system [4]. Such patterns as well as rising energy consumption are depleting natural resources and degrading the environment [5]. To meet the need of the present generations without compromising the ability of future generations to meet their needs, sustainable development is fundamental $[6,7]$. Today, it is

\footnotetext{
* e-mail: msengig99@yahoo.com
}

essential that communities and governments place more emphasis on ensuring that economic development is achieved in a sustainable way. To achieve sustainability, and improve the quality of our environment, it is essential to use renewable energies and energy efficiency measures that ultimately will reduce energy consumption and air pollution $[6,8]$. It is also important for governments, businesses, organizations, colleges, and universities to enact policies that incorporate practices and technologies that are designed to promote sustainability.

\subsection{Understanding sustainability}

The United Nations report linked environmental sustainability and economic development. The Brundtland Commission stated sustainability as "development that 
meets the needs of the present without compromising the ability of future generations to meet their own needs" [7, p. 15]. This is a widely recognized definition of sustainable development. Recently, sustainability has become a popular concept in environmental, health, policy, and research domains [9]. There is an increased knowledge and awareness regarding issues surrounding sustainability. The current prevailing definition refers to sustainability as a "dynamic equilibrium in the process of interaction between a population and the carrying capacity of its environment such that the population develops to express its full potential without producing irreversible, adverse effects on the carrying capacity of the environment upon which it depends" [10, p. 3]. Sustainability has been extensively discussed as involving all aspects of economic, environmental, and social domains.

\subsubsection{Economic aspect}

From the economic perspective, sustainability can be synthesized to include the conservation of natural capital as an essential element for sustainable economic growth. The assumption is that markets do not necessarily operate effectively to conserve "natural capital" [11, p. 4] but may tend to deplete and degrade it $[12,13]$. Early proponents of economics of sustainability argued that environmental protection policies are likely to stimulate innovation that can lead to economic achievement [14]. For example, Porter and van der Linde argued that pollution is a sign of poor and inefficient resource utilization [15]. The environment and the economy could both benefit through new technological innovations designed to reduce pollution and increase efficiency during the production process. Hence, good environmental policies that receive public support can stimulate new technological innovations that enhance production and energy efficiency while protecting our environment [16]. The link between the environment and economic development is, therefore, a strong justification for protecting the environment [14]. The inherent interdependence between the long-term stability of the environment and the economic development laid the foundation for the new concept of "Sustainable Development" [5,14].

The economic aspect of sustainability implies a system of production that satisfies present consumption levels without compromising future needs [17]. Economic sustainability seeks sustainability of the economic system itself [17]. In addition, sustainable development is also about sustaining the idea of improvement of the human condition, economic growth, as well as the importance of a balance between economic growth and environmental protection [9]. The UN Department of Economic and Social Affairs report on achieving sustainable development highlighted the key principles to achieving economic sustainability: (1) integrating the three pillars to sustainable development [economic growth, social development, and protection of the environment] in policy making and national planning, sources of energy such as fossil fuels (crude oil, coal, etc.), (2) raising cost of food and energy, (3) the threat of climate change and deterioration of our natural environment, and (4) promoting transfer of energy and resource-efficient modern technologies and affordable renewable energy systems [18].

\subsubsection{Environmental aspect}

According to Harris, an environmentally sustainable system must maintain a stable resource base, investing in substitute resources, while avoiding over-exploitation of both renewable or depleting non-renewable resources [13]. This includes maintaining biodiversity and stability of the atmospheric system. From the environmental perspective, assumption is that; in order to maintain the integrity of ecosystems and diversity of species, there needs to be a balance between population and the scale of total resource required [13]. Environmental sustainability also examines the impact of climate change in relation to high temperatures and the exacerbation of cardiovascular diseases and respiratory diseases as well as emerging and re-emerging of human diseases [19].

\subsubsection{Social aspect}

Despite being integrated late into the sustainable development debate, societal sustainability calls for social equality, justice, safety (receive protection in vulnerable circumstances), sustainable urban form (urban planning/spacing, built environments, land use), and eco-prosumption (mode of production and consumption, clean energy, reduce, reuse, recycle) $[17,20]$. Other aspects of social sustainability include social capital, social interaction, collective groups, and networks community or societal stability, the fulfillment of basic health and educational needs, and participatory democracy $[14,17]$. These are viewed as critical elements of sustainable development, but are also interrelated with environmental sustainability. Specific conditions must prevail in order to achieve social sustainability, including individual autonomy and realization of individual potentials, participatory democracy, justice, good citizenry and service to others, advancement in knowledge and resources to support it, safety and security, and good standard of living, and pride or sense of place $[14,17,19,20]$.

\subsection{Human behavior and sustainability}

Environmental and ecosystem sustainability are crucial to human life and well-being [21,22]. The exponential population growth (7.6 billion) translates into more need for ecosystem services such as food, water, shelter, and energy. Human behavior such as mining, deforestation, and other socioeconomic activities can significantly compromise the sustainability of the ecosystem to support shortterm and long-term human needs [21,22]. The UN 2030 agenda for sustainable development recognizes the need for prosperous life for all people as a way to foster sustainable development. Critical to this agenda is to end poverty and hunger, protect the planet, foster peace and prosperity, and strengthen global solidarity through strengthening partnerships [23]. This new global sustainable development goal agreed upon by heads of states and governments can transform unsustainable behaviors. 


\subsection{Sustainability and energy}

According to Harris, depletion of natural resources coupled with human-driven environmental impacts, especially the accumulation of greenhouse gasses, call for alternative energy supplies [13]. Sustainability experts suggest that nonfossil energy systems should be decentralized, adaptive to local conditions, and take advantage of innovative technologies (e.g., wind, geothermal, biomass, waves/tidal power, solar thermal energy, biofuel, bioenergy, and ongrid solar power systems) [24]. For instance, China recently developed the world's largest floating solar farm atop a former coal mine in an effort to shift reliance of energy from coal. According to the Chinese Daily report, the 40-MW power plant can power up 15,000 homes [25]. Renewable energy technologies that turn solar, wind, water, thermal, and plants into usable form of energy can have significant economic impact [26]. The International Renewable Energy Agency report indicates that doubling the share of renewables in the global energy mix would increase global GDP up to $1.1 \%$ or US $\$ 1.3$ trillion by 2030 . Also, doubling the share of renewables would increase direct and indirect employment in the renewable energy sector to 24.4 million people in 2030. In addition, renewable energy will improve human well-being and overall welfare by $2.7 \%$ beyond gains in GDP (0.6\%).

\subsection{Theoretical approaches and models of sustainability in higher education}

There are many theoretical frameworks and models that help explain the need for sustainability. For example, Jenkins states that theories of sustainability prioritize as well as integrate social responses to environmental and cultural problems [27]. Jenkins further stipulates three models of sustainability. These are economic model, ecological model, and political model. The economic models focus on sustaining opportunities mainly in the form of capital [27]. Drawing this argument from the proponent of the economic model, Solow further argues that sustainability should be thought of as an investment problem where returns must be used from utilizing natural resources to generate new opportunities of equal or greater value [28]. Daly casts sustainability in a different perspective in which the future requires strong conservation steps in order to preserve the ecological commodities and maintain economies that operate in respect to natural limits [29]. Furthermore, ecological models focus on sustaining biological diversity and ecological integrity through balanced maintenance of the ecosystem. Thus, indispensable natural resources must be maintained. Political models focus on the effects local and global environments have on the human dignity. Hence, it is supposed to maintain social systems that recognize human dignity by maintaining environmental conditions that support human life.

However, in higher education, sustainability can be understood in leadership and strategy theoretical frameworks [30]. Institutional commitment and leadership are important. Leadership is viewed as a key component in shaping the future of institutions of higher learning. Institutional commitment and leadership is a driver in sustainable outcomes. A leader is capable of fueling change on campuses [30]. Without leadership that views sustainability positively, campus sustainability efforts bare no fruits. Leaders can attract the necessary resources and compliance required for sustainability programs to succeed. Additionally, leaders control political and financial resources that can be utilized to direct the implementation of sustainability programs and research on college campuses [30]. A number of institutions of higher education still face challenges responding to initiatives for sustainability [31]. However, a set of logical guidelines that inform the process, plan to implement sustainability, and leadership to steer the process are necessary [31]. These logical guidelines also involve creating a comprehensive strategic plan that is weaved into the long-term institutional strategy. Students, faculty, staff, and stakeholders should be involved in the development and implementation of the strategic plan at every levels of the university hierarchy.

\subsection{Sustainability in higher education}

Campus sustainability is fundamental for any university. It necessitates improved academic infrastructures, setting right faculty priorities and practices. Campus sustainability ensures its practices reflect sustainability and raises awareness to the university community $[32,33]$. Campus sustainability denotes university potential to develop new ideas regarding sustainability through research, teaching, and practices $[32,34]$. Institutions of higher education are essential stakeholders in fostering understanding and forging a way forward in achieving a sustainable future $[35,36]$. Over the past years, many campuses across the world have invested significant effort, attention, and resources toward developing sustainable campus [37]. Universities and other higher learning institutions have been integrating sustainable development values and practices into their core teaching activities, research, institutional management, and operational systems [38]. However, implementing sustainability practices across all aspects of the university operations can be difficult due to budget cuts, competing priorities, and demands from students, faculty, and staff [39]. Some institutions of higher learning still debate the need for sustainability measures. A higher education institution that seeks to adopt sustainability measures goes through the following stipulated phases:

(1) Grassroots phase: Here campus grassroots efforts are made to advocate for numerous campus-wide sustainability-related services and policies such as recycling, creating courses, limiting pesticide applications, boycotting plastic bottle water sales, etc.

(2) Executive acceptance phase: At this stage the leadership begins to see the value of efficiency programs that reduce cost and improve campus reputation.

(3) Visionary campus leader phase: At this point the university administration openly adopts a sustainability vision and incorporates sustainability into the university's vision and strategic plan. 
(4) Fully self-actualized and integrated campus community phase: At this level the university aspires to and encourages others to incorporate sustainability in all spheres of campus life [39].

Therefore, initiating campus sustainability requires improved academic infrastructures, relevant faculty priorities, and university-wide awareness of sustainable practices [32].

\subsection{Study purpose}

This study assessed students' knowledge and awareness of "sustainability" efforts and practices on their campus. A campus that incorporates sustainability practices has "sustainability" incorporated into campus master plan, a sustainability strategic plan for short and long terms, and sustainability-related major or minor study program(s) focusing on sustainability (e.g., study abroad programs, student clubs, and events that focus on sustainability). Additionally, a university should have a sustainability office and sustainability council made of faculty, students, and staff. Universities can also join entities such as the American Colleges and a University President's Climate Commitment (ACUPCC) signatories and be active participants in the Association for the Advancement of Sustainability in Higher Education (AASHE), as well as the Sustainable Tracking, Assessment and Rating System (STARS) [40-42].

\subsection{Research questions}

(1) Do students value sustainability issues on their campuses?

(2) Do students understand the concept of "sustainability and or sustainable development"?

(3) Are students aware of any sustainability efforts or practices on their campus?

(4) Have students taken any courses that incorporate sustainability?

\section{Materials and methods}

This quantitative cross-sectional descriptive study examined college/university students' knowledge and awareness of sustainability and its environmental, economic, and social significance in an academic setting. The study also examined campus behavior and practice toward sustainable development.

\subsection{Sample}

Seventy-three students from various degree programs across departments in a Southeastern Texas university were purposefully selected and presented with a questionnaire in order to gauge the knowledge and awareness of sustainability themes, practices, and behaviors. Students 18 years of age and above, academic classification, nationality, and residence type participated in this study.

\subsection{Instrument}

A Sustainability Questionnaire was utilized to collect data after an approval from the university's Institutional Review Board. Questions in this questionnaire were adopted from the AASHE Stars Campus Sustainability Survey (Grand Valley State University) and the University Leaders for a Sustainable Future (ULSF) [43,44]. Some of the questions were modified to fit the need for this particular study. The questionnaire consisted of seven categories, namely, leadership, campus-wide sustainability effort, student activities, recycling, energy, transportation and food, and curriculum. Each category had a range of three to nine questions for a total of 40 question items and some open-ended questions. Most questions were designed to provide "yes", "no", or "not applicable" responses. The questionnaire was then pilot tested among 10 students for validation before being administered on a larger scale.

\subsection{Data collection}

The data collection process was conducted by three trained student researchers. Student researchers visited various programs in different departments on campus and asked volunteers to complete a 15-min anonymous, self-report questionnaire. No incentives were provided.

\subsection{Data processing and analysis}

The data were analyzed using SPSS v. 24 statistical program. Responses were entered into the SPSS and arbitrarily coded ( $1=$ yes; $2=$ no, and $3=$ not applicable). The analysis consisted of descriptive statistics, generating frequencies and percentages to provide sample characteristics.

\section{Results}

\subsection{Demographics}

The total sample was $73(N=73)$. In all, about $64 \%$ $(n=47)$ were females. About $20 \%$ of the participants were freshmen, $29 \%$ were sophomore, $25 \%$ were juniors, $21 \%$ were seniors, and 4 did not indicate their classification. Table 1 has the age range of the respondents.

A total of $53.4 \%$ of the respondents were staying in an apartment, $43.8 \%$ were staying in a house, and two did not indicate their resident type. The respondents varied across all the majors with a higher number (greater than six) of respondents from Engineering, Business, Health Education, Nursing, and General Studies.

\subsection{Importance of sustainability}

In answering whether sustainability is important on university campuses, the majority (95.8\%) responded "Yes". We examined the seven dimensions of sustainability, and Table 2 summarizes our finding to the sustainability awareness dimensions.

From Table 2, we further explored the dimensions of concern. The leadership dimension is one of particular 
Table 1. Age group of the participants.

\begin{tabular}{lll}
\hline Age range & $n$ & $\%$ \\
\hline $17-19$ years & 18 & 25 \\
$20-22$ years & 29 & 40.3 \\
$23-25$ years & 14 & 19.4 \\
26 years or older & 11 & 15.3 \\
Total & 72 & 100 \\
\hline
\end{tabular}

Note. One respondent did not disclose age.
Table 2. Sustainability awareness dimensions.

\begin{tabular}{llllll}
\hline $\begin{array}{l}\text { Sustainability } \\
\text { awareness }\end{array}$ & $\begin{array}{l}\text { Number } \\
\text { of items }\end{array}$ & $N$ & $\begin{array}{l}\text { Yes } \\
(\%)\end{array}$ & $\begin{array}{l}\text { No } \\
(\%)\end{array}$ & $\begin{array}{l}\text { N/A } \\
(\%)\end{array}$ \\
\hline $\begin{array}{l}\text { Leadership } \\
\text { Campus-wide efforts }\end{array}$ & 3 & 73 & 31.97 & 20.10 & 47.97 \\
Student activities & 9 & 73 & 32.65 & 47.02 & 20.33 \\
Recycling & 5 & 73 & 38.20 & 45.81 & 15.96 \\
Energy & 5 & 73 & 55.90 & 32.60 & 11.48 \\
$\begin{array}{l}\text { Transportation } \\
\text { and food }\end{array}$ & 7 & 73 & 48.08 & 40.26 & 21.64 \\
Curriculum & 5 & 73 & 30.94 & 47.96 & 21.08 \\
\hline
\end{tabular}

Table 3. Campus-wide effort on sustainability awareness.

\begin{tabular}{lllll}
\hline Question & $N$ & Yes (\%) & No (\%) & N/A (\%) \\
\hline Sustainability office/center with full-time staff & 73 & 21.9 & 53.4 & 24.7 \\
Campus energy manager & 73 & 21.9 & 53.4 & 24.7 \\
Student government focused on sustainability & 73 & 50.7 & 35.6 & 13.7 \\
Recycling manager & 73 & 41.1 & 43.8 & 15.1 \\
Sustainability component in the current strategic plan & 73 & 17.8 & 56.2 & 26.0 \\
Use water conservation devices & 73 & 42.5 & 39.7 & 17.8 \\
\hline
\end{tabular}

Table 4. Student activities on sustainability awareness.

\begin{tabular}{|c|c|c|c|c|}
\hline Question & $N$ & Yes $(\%)$ & No $(\%)$ & $\mathrm{N} / \mathrm{A}(\%)$ \\
\hline $\begin{array}{l}\text { The university participation in the campus climate } \\
\text { challenge }\end{array}$ & 73 & 27.4 & 49.3 & 23.3 \\
\hline $\begin{array}{l}\text { Student clubs/ groups/focused on sustainability } \\
\text { (such environmental outreach or recycling) }\end{array}$ & 73 & 72.6 & 23.3 & 4.10 \\
\hline $\begin{array}{l}\text { Major campus events related to sustainability } \\
\text { such as symposia or earth day }\end{array}$ & 73 & 50.7 & 37.0 & 12.3 \\
\hline Sustainability in new student orientation & 73 & 35.6 & 43.8 & 20.5 \\
\hline $\begin{array}{l}\text { Space dedicated to sustainability in a student } \\
\text { newspaper }\end{array}$ & 73 & 39.7 & 46.6 & 13.7 \\
\hline $\begin{array}{l}\text { Student ran café that serves environmentally or } \\
\text { socially preferable foods }\end{array}$ & 73 & 37.0 & 46.6 & 16.4 \\
\hline Student publication focused on sustainability & 73 & 26.0 & 57.5 & 16.4 \\
\hline $\begin{array}{l}\text { Outreach materials about on-campus sustainability } \\
\text { efforts, such as information kiosk }\end{array}$ & 73 & 35.6 & 47.9 & 16.4 \\
\hline On-campus, organic garden for students & 73 & 19.2 & 60.3 & 20.5 \\
\hline
\end{tabular}

interest. Though the majority of the students (54.8\%) agreed that the university advocates for policies that promote campus sustainability, about $60 \%$ do not have knowledge on whether or not the university has signed the "American college and university presidents climate commitments," nor do they know whether the university is a member of "the association for the advancement of sustainability in higher education."

Another area of concern is the campus-wide effort on sustainability awareness (see Tab. 3).
These results show that students indicated that at the organizational level, sustainability is not embedded into the strategic plan and majority of the students were not aware of a personnel at the university level spearheading sustainability efforts.

On the other hand, the dimensions on student activities show that there is some focus on sustainability (see Tab. 4).

About $72 \%$ of the sample indicated that student clubs engage in environmental outreach or recycling as well as earth day. However, $43 \%$ of the students reported that 
Table 5. Students' awareness on recycling.

\begin{tabular}{|c|c|c|c|c|}
\hline Question & $N$ & Yes $(\%)$ & No $(\%)$ & $\mathrm{N} / \mathrm{A}(\%)$ \\
\hline Campus-wide recycling program & 73 & 47.9 & 39.7 & 12.3 \\
\hline On-campus recycling center & 73 & 42.5 & 42.5 & 15.1 \\
\hline Computer or e-waste recycling & 73 & 30.1 & 53.4 & 16.4 \\
\hline $\begin{array}{l}\text { The university limiting free printing in computer } \\
\text { labs and libraries }\end{array}$ & 73 & 79.5 & 13.7 & 6.80 \\
\hline $\begin{array}{l}\text { The University replacing paper materials, such as } \\
\text { course catalogs, registration, course syllabus, directories, } \\
\text { with online option }\end{array}$ & 73 & 79.5 & 13.7 & 6.80 \\
\hline
\end{tabular}

Table 6. Students' awareness through curriculum.

\begin{tabular}{lllll}
\hline Questions & $N$ & Yes (\%) & No (\%) & N/A \% \\
\hline Sustainability-focused course(s) such as environmental health & 73 & 26.0 & 52.1 & 21.9 \\
Sustainability-focused undergraduate major & 73 & 27.4 & 49.3 & 23.3 \\
Sustainability study abroad program(s) & 73 & 37.0 & 42.5 & 20.5 \\
Sustainability focused internship & 73 & 34.2 & 45.2 & 20.5 \\
Sustainability-focused, nonacademic certificate program(s) & 73 & 30.1 & 50.7 & 19.2 \\
\hline
\end{tabular}

sustainability was not included in the student orientation program and $57 \%$ reported that their student publications did not focus on sustainability. The majority of the students $(60 \%)$ also indicated that there was no on-campus organic garden for students.

Within the dimension of recycling, most of the students $(79 \%)$ reported that the university limits free-printing in computer labs and libraries and they have noticed that paper materials such as course catalogs and directories are being replaced with online options. See Table 5 for full details.

Another dimension of interest is the curriculum, which is a major means through which sustainability practices are communicated to students. More than half of the students surveyed indicated that there were no courses or programs that focused solely on sustainability issues (see Tab. 6).

Finally, students' awareness in terms of energy, transportation, and food-related sustainability issues indicated that a lot of positive initiatives have been undertaken. For example, the majority of students selfreported awareness of motion sensors, the use of LED lighting, free campus transportation, and availability of bike racks except the availability of organic produce in the on-campus dining facilities.

\section{Discussion}

The purpose of this study was to examine the concept of sustainability among college students. The study also assessed student's awareness of sustainability efforts or practices undertaken on their campus and to also verified if sustainability issues are incorporated in their curricula. The results showed mixed findings. First, a majority of the students acknowledged the importance of sustainability. Common themes from students' narratives regarding what sustainability meant to them include "saving the environment," "keeping environment viable," "clean," "livable," "sustaining," "going green," and "long-term life on earth."

This promising finding suggests that sustainability campaigns, advertisements, and promotions at the national, regional, and local levels are making an impact especially on college-age students. It is important to note that there have been a number of recent sustainability measures implemented at the university where these data were collected. The value of a sustainable environment has been an important issue to millennials. The literature on campus sustainability issues argue that more and more universities are indeed developing or fostering sustainability projects. Our results suggest a bottom-up grassroots effort from students as a relevant first step for any campus sustainability program to succeed [39]. Sustainability efforts or studies should involve students, faculty, staff, and other stakeholders to design, develop, implement, and lead most of the sustainability efforts. These groups take into consideration the need, equity, and ethics in translating global sustainability concerns into design decisions $[45,46]$.

Of the seven dimensions of sustainability awareness measured, recycling received the highest overall awareness score. Students were aware of various recycling activities on 
campus. This finding is not surprising because recycling practices, symbols, and initiatives are usually visible on university campus buildings and residence halls. Other dimensions such as leadership, campus-wide effort, and curriculum received the lowest score. This could be attributed to lack of obvious effort that promotes sustainability and integration of sustainability into various program curricula.

\section{Conclusion and recommendations}

This study reveals students' level of knowledge and awareness of sustainability efforts on campus. Overall, students lacked basic knowledge on sustainability and furthermore were not aware of efforts made, the university, as well as courses offered on sustainability and environmental health. Universities have the ability to educate and empower students to believe in and take the necessary steps and actions to promote economic, environmental, and societal change that brings about a healthier and sustainable world.

To date, while many institutions of higher learning acknowledge the need for sustainability to be at the center of the institution's daily operations, the issue remains how best sustainability and the environment can be made a cornerstone of academic practice [30]. There is a growing consensus that economic and societal benefits can be achieved when there is healthy and sustainable environment. Successful long-term sustainability efforts require committed champions such as faculty or staff members [47]. Students, despite being very transitory for them, can play an important role in initiating sustainability programs. The common challenge for sustainability efforts on campuses for faculty, staff, and students is the lack of financial support that is needed for implantation of campus-wide sustainability initiatives. However, institutions can solicit fees from students or set aside operation budget to hire a staff to run sustainability initiatives; certain conditions must prevail for sustainability initiatives and programs to succeed in higher education institutions.

\subsection{Campus-wide sustainability}

Campus-wide sustainability efforts and engagement must be fostered. All educational programs, research, and services must be geared toward cultivating behavior and thinking pattern that foster sustainability. Faculty, staff, and students must be involved in various sustainabilitypromoting activities. Cocurricular activities foster sustainability culture into campuses. A study by Brinkhurst et al. found that faculty and staff members were critical leaders in efforts to achieve lasting progress toward campus sustainability [48].

\subsection{Curriculum}

A curriculum that can train students to understand sustainability and address sustainability challenges is necessary. In degree programs there is a need to develop sustainability-related courses. These courses can focus on the three dimensions of sustainability such as economic prosperity, environmental health, and social well-being
[49]. These courses will introduce students to the concept of sustainability as well as build knowledge about each sustainability dimension.

\subsection{Research}

Research is a major component of university academic rigor. Research can facilitate the understanding of best practices, technologies, and approaches to solving sustainability issues. A university can create and use tools such as campus carbon calculator or sustainable solutions to measure carbon emissions and energy management efforts [47].

\subsection{Partnership and engagement}

University-community partnership and engagement is important in enhancing sustainability efforts on college campuses. Engaging the wider community has strong impact on solving sustainability challenges. Universitycommunity partnerships can offer an opportunity to understand the challenges that people face in communities, encourage local sustainability innovations, and contribute to policy development at various levels of local communities [50]. University-community partnership can also serve as a tool for students to sharpen their leadership skills and real-world problem-solving skills. Overall, this partnership should involve education and outreach activities and programs. The education and outreach activities can increase environmental sustainability and energy awareness on- and off-campuses.

\subsection{Sustainable buildings}

Campus buildings are major consumers of water, energy, and source of greenhouse gas emissions. Designing and building sustainable buildings will promote sustainability [51]. To reduce campus greenhouse emissions, a campus can implement high-efficiency upgrades, such as installing building meters that monitor and compile data on flows of electricity, water, and steam. Other measures include installation of efficient water toilets, heating systems, building automations to control air-conditioning, and wider modern windows to allow more light into the building, combined with shading, insulation, and ventilation. Today, many modern institutions of higher learning are investing in green building designs. Energy-efficient buildings reduce energy consumption and greenhouse gas emission almost immediately [52].

\subsection{Energy efficiency}

Campuses utilize lots of energy for heating and cooling, lighting, cooking, and running electronics such as computers. Energy-saving measures such as installation of clean renewable energy can reduce consumption of (fossil) energy and greenhouse gas emissions and can save money [53]. Campuses can implement low-cost-efficiency upgrades, launch campaign on energy utilization awareness, and promote energy-conserving behaviors. Energyconserving behaviors include turning off light, computers, and other appliances when exiting classes, offices, labs, and 
dormitories. Also, purchase of energy star items, use of LED light, and adoption of efficient heating policies can have significant reduction in energy cost. Turning to renewable energy sources such as solar, biomass, and wind along with decreased reliance on nonrenewable resources (e.g., oil, natural gas, and coal) is also beneficial.

\subsection{Food and dining services}

Universities can buy food locally to support local economies. However, universities can create demand for organically grown food; hence, slowly impact food production systems thereby support sustainable environment. Dining service can reduce food waste by creating better food options and educating students. Sustainable dining efforts based on seasonally prioritized locally grown food from sustainability practicing farmers are important initiatives to be implemented. This food must be organic, such as eggs from free-range chicken, vegetables, fruits, dairy products, honey, and all grain-based foods.

\subsection{Purchase of environment-friendly products}

Purchasing environmentally preferable products can help preserve natural resources as well as reduce cost and pollution. Universities can purchase recycled papers with $30 \%$ or more recycled materials and chlorine-free papers, purchase biodegradable dishware, reusable bottles, and green cleaning products with low volatile organic compounds (VOC). Also, purchasing environment-friendly and socially preferable products and services support growth and expansion of companies with strong commitment to suitability and environmental health [41].

\subsection{Reduction of vehicle use}

Globally, transportation sector is the largest contributor of greenhouse gas emissions and particulate matter (PM) [54]. These soot and metal particles give smog its cloudy color. Small particles as $10 \mu \mathrm{m}$ in diameter can penetrate deep into the lungs and become a threat to human health [54]. Nearly $28.5 \%$ of greenhouse gas emissions come from the United States and 14\% come globally from the transportation sector [55]. These emissions pollute the air, water, and soil. Emissions from vehicles and other forms of transportations have been epidemiologically and clinically linked to major health problems such as cardiovascular diseases, cancer, impaired immune systems, birth defects, genetic mutations, asthma, cystic fibrosis, diabetes, chronic obstructive pulmonary disease (COPD), and eye diseases [56]. Students, faculty, and staff can implement innovative approaches to reduce vehicle usage by initiating programs such as ride your bicycle to class, carpooling/ sharing, public transport, and universities purchasing hybrid vehicle fleet. These efforts can positively impact sustainability efforts and cost reduction.

\subsection{Waste management}

Waste production due to manufacturing, distribution, use, and disposal of these products negatively affects the environment and human health. Improper handling of waste creates a potential risk to school children, waste workers, and communities living in nearby areas with improper waste management program [57]. Institutions of higher learning generate all kinds of wastes, including recyclables (paper, cardboard, aluminum, and household batteries), e-waste (old computers and hardware), florescent light bulbs, as well as biological, chemical, and radioactive wastes from research activities. These institutions should focus on strategies to minimize waste production; for instance, implementing proper inventory of supplies before ordering new ones, ordering only what is needed, and reuse and recycling. In order to address the root cause of waste production, waste diversion and source reduction (how products are designed and produced) must be examined [58]. Waste diversion can cut cost universities spend on collecting and transporting solid waste to landfills. Furthermore, campus-wide campaigns on waste reduction must be initiated and implemented to contribute to the long term of campus attitude change.

Even though this university study has a sustainability component as one of its strategic goals, many students were unaware of the definition of sustainability. To effectively implement and foster sustainability, concerted effort must be employed to infuse sustainability in every aspect of campus life. Principles and goals of sustainability must be communicated effectively throughout the institution. In addition, AASHE offers valuable workshops to support faculty and other individuals designing curriculums.

This study was limited to 73 students at a Southeastern Texas university. Findings cannot be generalized to all students or other institutions of higher learning in Southeastern Texas and beyond. We recommend a follow-up study to assess current awareness and implementation of sustainability on campus. The study can be expanded to include students, faculty, staff, and administrators. Additionally, there is a need to extrapolate this study to include more universities and increase sample size.

\section{Implications and influences}

To date, numerous institutions of higher learning are recognizing the moral imperative associated with sustainability. However, a majority of academic programs, curricula, courses, and general practices of these institutions do not reflect the integration of sustainability initiatives. This study revealed that most participants were neither aware of campus sustainability initiatives nor able to clearly define sustainability. This demonstrates the existence of a bigger problem beyond students knowing the definition of sustainability. It reflects the institutions' slow pace or hesitance to change the culture of business as usual. Our findings show that sustainability is not a new phenomenon in institutions of higher learning, but adoptions of sustainability initiatives into campus life is still an ongoing challenge. Hence, there is a need to continue advocating for integration of sustainability initiatives into campus life. Faculty, students, and staff, with the support of university leadership, are likely to spearhead successful sustainability initiatives on university 
campuses. Advocating for sustainability and evaluation of implementations of these initiatives on a continuous basis is essential. Hence, we think advocates should utilize creative strategies when accessing institutional resources. That way, with visible positive outcomes, they will gain legitimacy and ultimately lead to institutionalization of sustainability initiatives.

\section{Author contribution statement}

Israel Msengi conceptualized the study, wrote the draft, literature review, and methodology, and supervised HEEC student to collect the data. Raymond Doe analyzed the data and wrote the Results section. Twana Wilson, Danny Fowler, Chelsey Wigginton, Sarah Olorunyomi, Isaiah Banks, and Raquel Morel collected data for this study and presented findings at the conference.

\section{Funding}

This research received no funding from any sources.

\section{Conflicts of interest}

The authors declare no conflicts of interest.

\section{References}

1. M.L. Fleming, T. Tenkate, T. Gould, Ecological sustainability: what role for public health education? Int. J. Environ. Res. Public Health 6, 2028 (2009)

2. P. Goymer, Sustainable ecosystem and society. Nature 515, 49 (2014)

3. E.A. Hernandez-Delgado, The emerging threats of climate change on tropical coastal ecosystem services, public health, local economies and livelihood sustainability of small islands: cumulative impacts and synergies. Mar. Pollut. Bull. 101, 5 (2015)

4. J. Morelli, Environmental sustainability: a definition for environmental professionals. J. Environ. Sustain. 1, 19 (2011)

5. International Union for Conservation of Nature and Natural Resources (IUCN) \& United Nations Environmental Program (UNEP), World Conservation Strategy: Living Resource Conservation for Sustainable Development (1980). Available at http://www.a21italy.it/medias/31C2D26FD81B0D40.pdf (accessed February 14, 2018)

6. National Institutes of Environmental Health Sciences (NIEHS), NIEHS Sustainability Report (2011). Available at https://www.niehs.nih.gov/health/materials/global_en vironmental health and sustainable development $5 \overline{0} 8$. pdf (accessed November $\overline{20}, 2017$ )

7. United Nations General Assembly, Report of the World Commission on Environment and Development: Our Common Future, United Nations General Assembly, Development and International Co-operation: Environment, Oslo, Norway (1987). Available at http://www.un-docu ments.net/our-common-future.pdf (accessed May 15, 2018)
8. U.S. Department of Health and Human Services, Strategic Sustainability Performance Plan (July 2016). Available at https://www.hhs.gov/sites/default/files/2016-sustainabili ty-plan.pdf (accessed January 2018)

9. I.M. Simion, C. Ghinea, S.G. Maxieasa, N. Taranu, A. Bonoli, M. Gavrilescu, Ecological footprint applied in the assessment of construction and demolition waste integrated management. Environ. Eng. Manage. J. 12, 779 (2013)

10. M. Ben-Eli, Sustainability: Definition and Five Core Principles. A New Framework, The Sustainability Laboratory (2015). Available at http://www.sustainabilitylabs.org/assets/img/ SL5CorePrinciples.pdf (accessed February 3, 2018)

11. Asian Development Bank, Investing in Natural Capital for a Sustainable Future in the Greater Mekong Subregion (2015). Available at https://www.adb.org/sites/default/files/publi cation/176534/investing-natural-capital-gms.pdf (accessed March 11, 2018)

12. J.M. Harris, Basic Principles of Sustainable Development, Global Development and Environmental Institute: Working Paper 00-04, Tufts University (2000). Available at http:// www.ase.tufts.edu/gdae/publications/working_papers/Sus tainable\%20Development.pdf (accessed December 7, 2016)

13. J.M. Harris, Sustainability and Sustainable Development, International Society for Ecological Economics, Internet Encyclopedia of Ecological Economics (2003). Available at http://isecoeco.org/pdf/susdev.pdf (accessed October 11, 2017)

14. R. Emas, Brief for GSDR: The Concept of Sustainable Development: Definition and Defining Principles, Florida International University (2015). Available at https://sustaina bledevelopment.un.org/content/documents/5839GSDR\% 202015_SD_concept_definiton_rev.pdf (accessed June 5, 2017)

15. C. van der Linde, M.E. Porter, Green and competitive: ending the stalemate. Har. Bus. Rev. 73, 120 (1995)

16. M.E. Porter, C. van der Linde, Toward a new conception of the environment competitiveness relationship. J. Econ. Perspect. 9, 97 (1995)

17. A.D. Basiago, Economic, social and environmental sustainability in development theory and urban planning practice. Environmentalist 19, 145 (1998)

18. Unit ed Nations Department of Economic and Social Affairs, Achieving Sustainable Development and Promoting Development Cooperation. Dialogue at the Economic and Social Council (United Nations Publications, New York, 2008)

19. T.L. Reddy, R.J. Thomson, Environmental, Social and Economic Sustainability: Implications for Actuarial Science, Actuaries Institute ASTIN, AFIR/ERM and IACA Colloquia, Sydney (2015). Available at https://www. actuaries.asn.au/Library/Events/ASTINAFIRERMCollo quium/2015/ReddyThompsonActuarialSciencePaper.pdf (accessed May 11, 2017)

20. E. Eizenberg, Y. Jabareen, Social sustainability: a new concept framework. Sustainability 9, 68 (2017)

21. L. Bizikova, Understanding the Contribution of the Environment to Human Well-Being: A Review of Literature. International Institute Sustainable Development (IISD) Report, 2011. Available at http://www.iisd.org/pdf/2012/ understanding contribution environment.pdf (accessed March 12, 2017)

22. C. Vlek, L. Steg, Human behavior and environmental sustainability: problems, driving forces, and research topics. J. Social Issues 63, 1 (2007) 
23. United Nations General Assembly (A/RES/70/1), Seventieth Session, Agenda Items 15 and 116, Transforming Our World: The 2030 Agenda for Sustainable Development, resolution adopted by the General Assembly (September 25, 2015). Available at http://www.un.org/ga/search/view_doc.asp? symbol $=\mathrm{A} / \mathrm{RES} / 70 / 1 \& \mathrm{Lang}=\mathrm{E}$ (accessed September 26, 2018)

24. N.J. Smith-Sebasto, Annual Editions: Sustainability, 1st edn. (McGraw Hill Companies, Inc., New York, 2013)

25. Global News, China Sets Up World's Largest Solar Farm, Boosts Bid to Lead Renewable Energy Charge. Available at https://globalnews.ca/news/3499997/china-solar-farm-re newable-energy/ (accessed June 20, 2018)

26. International Renewable Energy Agency, Renewable Energy Benefits: Measuring the Economics (2016). Available at http://www.irena.org/DocumentDownloads/Publications/ IRENA_Measuring-the-Economics_2016.pdf (accessed April 12, 2018)

27. W. Jenkins, Sustainability theory, in Berkshire Encyclopedia of Sustainability: The Spirit of Sustainability (Berkshire Publishing Group, Great Barrington, MA, 2009)

28. R.M. Solow, Sustainability: an economist's perspective, in Economics of the Environment: Selected Readings, edited by R. Dorfman, N.S. Dorfman, 3rd edn. (Norton, New York, 1993), pp. 179-187

29. H.E. Daly, Ecological Economics and Sustainable Development: Selected Essays of Herman Daly, Advances in Ecological Economics (Edward Elgar Publishing Limited, Cheltenham, UK, 2007), pp. 61-125

30. A.W. Bezbatchenko, Sustainability in colleges and universities: towards institutional culture shifts. J. Student Affairs New York Univ. 6, 1 (2010)

31. S.M. Posner, R. Stuart, Understanding and advancing campus sustainability using a systems framework. Int. J. Sustain. High. Educ. 14, 264 (2013)

32. R. Emanuel, J.N. Adams, College students' perceptions of campus sustainability. Int. J. Sustain. High. Educ. 12, 79 (2011)

33. A. Beynaghi, G. Trencher, F. Moztarzadeh, M. Mozafari, R. Maknoon, W. Leal Filho, Future sustainability scenarios for universities: moving beyond the United Nations decade of education for sustainability development. J. Cleaner Prod 112, 3464 (2015)

34. C. Shiel, Filho, W.L. do Paco, L. Brandli, Evaluating the engagement of universities in capacity building for sustainable development in local communities. Eval. Program Plan. 54, 123 (2016)

35. I. Abubakar, F. Al-Shihri, S. Ahmed, Students' assessment of campus sustainability at the University of Dammam, Saudi Arabia. Sustainability 8, 59 (2016)

36. D. Ferrer-Balas, J. Adachi, S. Banas, C.I. Davidson, A. Hoshikoshi, A. Mishra, Y. Motodoa, M. Onga, M. Ostwald, An international comparative analysis of sustainability transformation across seven universities. Int. J. Sustain. High. Educ. 9, 295 (2008)

37. W.L. Filho, L. Brandli, O. Kuznetsova, A.M.F. do Paco (Eds.), Integrative Approaches to Sustainable Development at University Level: Making the Links, World Sustainable Series (Springer, New York, 2015)

38. Organization for Economic Co-operation and Development (OECD), Higher Education for Sustainable Development, final report of International Action Research Project. Available at https://www.oecd.org/edu/innovation-educa tion/centreforeffectivelearningenvironmentscele/45575516. pdf (accessed May 10, 2018)
39. K.J. Krizek, D. Newport, J. White, A.R. Townsend, Higher education's sustainability imperative: how to practically respond? Int. J. Sustain. High. Educ. 13, 19 (2012)

40. American College, University Presidents' Climate Commitment (2018). Available at http://secondnature.org/ (accessed March 11, 2018)

41. The Association for the Advancement of Sustainability in Higher Education (AASHE), Campus Sustainability Hub. Available at https://hub.aashe.org/ (accessed November 13, 2017)

42. The Sustainability Tracking, Assessment \& Rating System (STARS). Available at http://www.aashe.org/wp-content/ uploads/2017/04/STARS-flyer.pdf (accessedSeptember 2, 2016)

43. Grand Valley State University, Campus Sustainability Survey (2011). Stars.AASHE.org. Available at https:// stars.aashe.org/media/secure/95/5/303/1693/Sustainabili ty\%20Questions\%202011.pdf (accessed September 2, 2016)

44. University Leaders for a Sustainable Future (2009). Sustainability Assessment Questionnaire (SAQ) for Colleges and Universities. Available at http://ulsf.org/wp-content/ uploads/2015/06/SAQforHigherEd09.pdf (accessed September 2, 2016).

45. H. Lewis, J. Gertsakis, Design and Environment: A Global Guide to Designing Greener Goods (Greenleaf Publications, Melbourne, 2001)

46. D. Deniz, Sustainable thinking and environmental awareness through design education. Proc. Environ. Sci. 34, 70 (2016)

47. J. Andrews, E. Farrell, C. Flaherty, J. Pearlman, The State of Sustainability in Higher Education 2015: Emissions Metrics, Consumption Trends and Strategies for Success (2015). Available at https://sustainableunh.unh.edu/sites/ sustainableunh.unh.edu/files/media/the_state_of_sustai nability_in_higher_education_2015.pdf (accessed February $5,2 \overline{0} 18)$.

48. M. Brinkhurst, P. Rose, G. Maurice, J.D. Ackerman, Achieving campus sustainability: top-down, bottom-up or neither? Int. J. Sustain. High. Educ. 12, 338 (2011)

49. J. Tylor, E. Kraly, The Role of Sustainability Curriculum in Higher Education, Colgate University. Available at http://www.colgate.edu/docs/default-source/default-doc ument-library/sustainability-in-higher-education-reportby-jenna-taylor.pdf?sfvrsn=0 (accessed October 11, 2017) (2012)

50. C. Kagan, R. Lawthom, O.D. Clennon, J. Fisher, J. Diamond, K. Goldstraw, Sustainable communities: university-community partnership research on social dimensions of sustainable development, in Sustainable Development Research at Universities in the United Kingdom World Sustainability Series, edited by W. Leal Filho (Springer International Publishing AG, Cham 2017), pp. 245-262

51. A. Sinha, R. Gupta, A. Kutnar, Sustainable development and green buildings. Drvna Industrija 64, 45 (2013)

52. Environmental Protection Agency (EPA), Local Government Climate and Energy Strategy Guide: Energy Efficiency in Water and Wastewater Facilities. A Guide to Developing and Implementing Greenhouse Gas Reduction Programs. Available at https://www.epa.gov/sites/production/files/ 2015-08/documents/wastewater-guide.pdf (accessed April $21,2017)$ 
53. S. Chen, J. Huang, A smart green building: an environmentally health control design. Energies 5, 1648 (2012)

54. United States Environmental Protection Agency (EPA), Greenhouse Gas Emissions. Sources of Greenhouse Gas Emissions. Available at https://www.epa.gov/ghgemissions/sources-green house-gas-emissions (accessed May 25, 2018)

55. United States Environmental Protection Agency (EPA), Greenhouse Gas Emissions, Global Greenhouse Gas Emissions Data, Global Emissions by Economic Sector. Available at https://www.epa.gov/ghgemissions/global-greenhousegas-emissions-data (accessed May 25, 2018)
56. H. Koren, Best Practices for Environmental Health: Environmental Pollution, Protection, Quality and Sustainability (Routledge, New York, 2017)

57. M. Medina, Solid Waste, Poverty and the Environment in Developing Country Cities, UNU World Institute for Development Economics Research (UNU-WIDER), Helsinki, Finland. Available at https://pdfs.semanticscholar.org / 964e / 0a865464af82a4d0e591682aa48df65129be.pdf (accessed January 13, 2018)

58. N. Yukalang, B. Clarke, K. Ross, Barriers to effective municipal solid waste management in a rapidly urbanizing area in Thailand. Int. J. Environ. Res. Public Health 14, 1 (2017)

Cite this article as: Israel Msengi, Raymond Doe, Twana Wilson, Danny Fowler, Chelsey Wigginton, Sarah Olorunyomi, Isaiah Banks, Raquel Morel, Assessment of knowledge and awareness of "sustainability" initiatives among college students, Renew. Energy Environ. Sustain. 4, 6 (2019) 